be linked to information about an individual's health, environment and family background. However, the use of genome data in research raises privacy and confidentiality issues. The Personal Genome Project model that Angrist describes represents one end of a spectrum. Its participants are advocates of biomedical research, actively involved in the field and able to understand the possible consequences of having their data posted online.

Direct-to-consumer testing is nearer the other end of the spectrum. Each consumer's genome information sits on a secure server maintained by the testing company, and it is up to each person how they share it. The popularity of this approach suggests that people trust the companies to hold their information and like being in control of who can see it. The downside is that the information is less accessible to researchers.

The challenge will be to reconcile people's concerns about genomic privacy and security with the need to allow researchers and clinicians data access. If personal genomics is offered largely by consumer testing, the onus will be on the companies to engage their customers in research projects that improve understanding of how our genomes influence health. Some have started to do this. For instance, 23andWe - the research arm of 23 andMe - recruits customers into research projects on pharmacogenomics, Parkinson's disease, sarcoma and aspects of pregnancy.

Alternatively, national or regional health-care systems concerned with disease prevention may offer genomic tests on a more systematic basis. A possible model might be the UK Biobank, which has recruited more than 500,000 people in a study to see how health is affected by lifestyle, environment and genes. Participants divulge medical and lifestyle information and donate biological samples from which researchers can generate gene sequences. The success of the project to date is largely a result of creating a robust, independent framework for ethics and governance, recruiting participants through trusted intermediaries (their physicians) and sharing the data with researchers in a form that hides the identity of individuals.

No amount of data will be useful if you can't interpret what they mean. We are reaching the point at which the cost of interpreting genome information will exceed the cost of generating it, so the challenge ahead will be to make more sense of the data we already have. We will also have to answer the question of whether genome data are personal, in that they are paid for and controlled by individuals, or whether such data are medical, being funded by and accessible to health-care systems.

Peter Border is biology and health adviser at the Parliamentary Office of Science and Technology, London, UK.

e-mail:peter.border@googlemail.com

\title{
A cultural history of the elements
}

\author{
Andrew Robinson enjoys a chemical romp from \\ aluminium to zinc.
}

$\mathrm{T}$ he familiar metallic taste of blood was explained scientifically only in the mid-eighteenth century. An Italian chemist and physician in Bologna, Vincenzo Menghini, roasted the blood of various birds, fish and mammals, including humans. He powdered the residue and passed a naturally magnetized lodestone close to the dried blood particles. Some were magnetically attracted, suggesting the presence of iron.

Science writer Hugh Aldersey-Williams successfully repeated Menghini's experiment in his kitchen using blood from chicken livers, a low oven and a moderately strong magnet. But why, he asks, did Menghini imagine that iron would be present in blood? The physician must have known that people with blood disorders were sometimes advised to take iron salts. In the sixteenth century, a principal iron ore was named haematite - the prefix 'haem' being derived from the Greek for blood. Western alchemists paired iron with the red planet Mars. The original connection between iron and blood seems to date to the Romans,

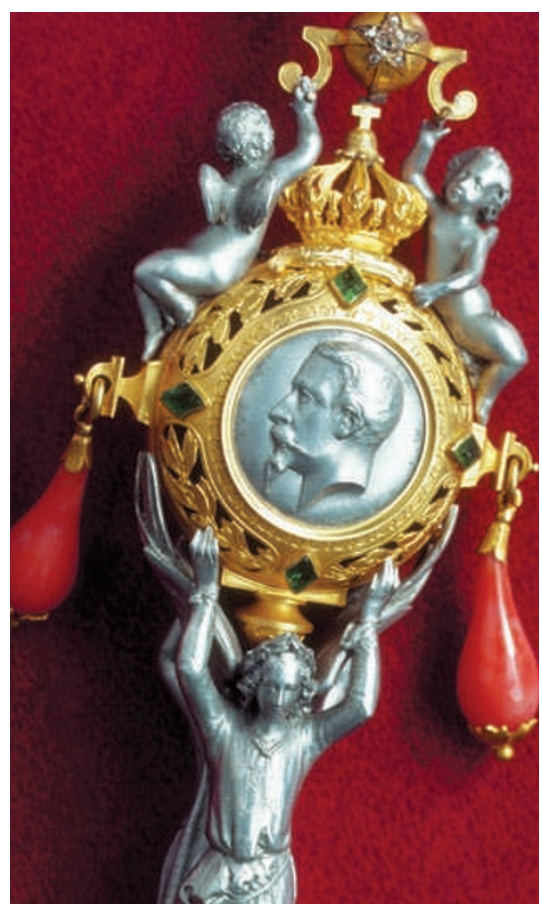

Prince Louis Napoleon's 1856 aluminium rattle.

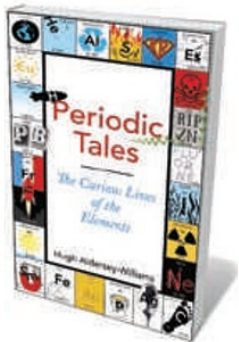

Periodic Tales: The Curious Lives of the Elements/A Cultural History of the Elements, from Arsenic to Zinc HUGH ALDERSEY WILLIAMS Viking/Ecco: 2011. 448 pp. $£ 18.99 / \$ 29.99$ who associated the two in their cult of the war god Mars.

Other entertaining elementary experiments conducted by the author involve phosphorus and iodine. Doubting the claim that rotting herrings emit light, he left some decaying fish in his garage. Two nights later, he observed the phosphorescent "glowing of the lifeless herring", mentioned by twentieth-century writer W. G. Sebald. Using local seaweed, AlderseyWilliams also prepared an intense violet vapour and black crystalline condensate of iodine. Here, he notes, he followed the poet Johann Wolfgang von Goethe, who in 1822 demonstrated iodine vapour and crystals for house guests in support of his controversial theory of colours.

For all its technical accuracy, Periodic Tales is neither a book of experiments nor a science book. Aldersey-Williams eschews the territory covered, for example, by Peter Atkins in The Periodic Kingdom (Basic Books, 1995). There are few references to atomic weight and atomic number, scarcely any chemical formulae and nothing on electrons and orbitals. There is no up-to-date periodic table among the quirky illustrations, merely the handwritten version created by Dmitri Mendeleev in 1869. Instead, the book is a cultural history of some of the chemical elements, dwelling on both their material presence in our lives and their figurative presence in art, literature, language, history and geography. Thus we come to know the elements individually, argues Aldersey-Williams, who regrets that his own formal chemistry education did so little to acknowledge such a "rich existence". So do I. $\rightarrow$ NATURE.COM For Nature's International Year of Chemistry special: go.nature.com/Iqunoj 
Aluminium, for example, was first named aluminum by Humphry Davy, who repeatedly tried to isolate it from its oxide, alumina. He followed the naming precedents set by platinum, molybdenum and tantalum. Then, in 1812, an anonymous reviewer of Davy's book Elements of Chemical Philosophy insisted on a name that sounded more "classical" - aluminium. Nonetheless, when use of the metal took off in the United States at the end of the nineteenth century, Americans plumped for the version that omits the letter 'i'. Not even the US literary critic H. L. Mencken could work out why in his 1919 book The American Language.

Aluminium enjoyed a brief mid-century vogue as a precious metal before the invention of the electrolytic separation process in 1886, still used today, which extracts it from bauxite (named after Les Baux in Provence, France, where the ore was found). In 1855, a French chemist, Henri Sainte-Claire Deville, managed to extract the metal by heating anhydrous aluminium chloride with sodium. But this was hugely expensive. His ingots worth a dozen times more than silver - were admired at the Paris Universal Exposition of 1855 by Emperor Napoleon III of France, who offered financial support to Deville. Such was the metal's rarity that a renowned goldsmith, Christofle, made hand-crafted aluminium jewellery and tableware, which was favoured at imperial banquets, and an aluminium rattle was given to the emperor's newborn son. Chemical elements, Periodic Tales emphasizes, can go in and out of fashion. Think of what happened to chromium plating.

Almost every page yields a nugget. The difficulty, however, is to find order and meaning. Aldersey-Williams settles for five sections, divided into chapters on one element or a group such as the halogens. 'Power' includes gold, iron, carbon, plutonium and mercury; 'Fire' includes sulphur, phosphorus, chlorine, oxygen and radium; 'Craft' — tin, silver, copper, aluminium and calcium; 'Beauty' - chromium, arsenic, vanadium, antimony and neon; and finally 'Earth', encompassing the rare earth elements and some other, less familiar ones. This division is workable, but I query some choices. Gold, for instance, surely belongs as much in 'Craft' and in 'Beauty' as in 'Power.' It also seems odd to omit a chapter on silicon, given its starring role in electronics.

That said, the book is imaginative and fun. Who can resist the information that an unofficial Dutch spectroscopic analysis of the five-euro banknote shows it to be impregnated with an anti-counterfeiting ink containing a little-known rare earth element - europium.

Andrew Robinson is a writer based in London, and author of The Story of Measurement.

e-mail: andrew.robinson33@virgin.net

\section{Books in brief}

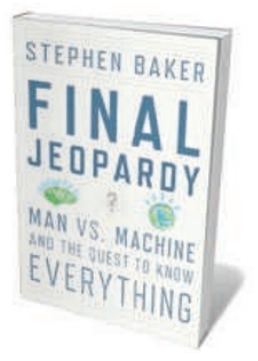

Final Jeopardy: Man vs. Machine and the Quest to Know Everything

Stephen Baker HOUGHTON MIFFLIN HARCOURT 288 pp. \$24 (2011)

For the past year, IBM researchers have been building a robot clever enough to compete in the US television quiz show Jeopardy! In mid-February, viewers in the United States will be able to watch a real contest between man and machine, when two previous winners take on the drone. Technology writer Stephen Baker describes in his book how artificial-intelligence researchers constructed the robot and the challenges they faced in getting 'Watson' to understand language, spot puns and recall general knowledge.

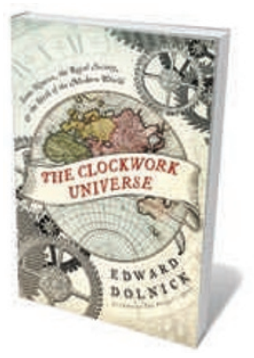

The Clockwork Universe: Isaac Newton, the Royal Society, and the Birth of the Modern World

Edward Dolnick HARPER 400 pp. \$27.99 (2011)

From a modern perspective, seventeenth-century science can appear strange. Rational descriptions of a clockwork Universe sat happily beside belief in omens, alchemy and the devil. By portraying the lives and discoveries of Johannes Kepler, Galileo Galilei, Isaac Newton and Gottfried Leibniz, science writer Edward Dolnick fleshes out these contradictions in the thinking of the time. Emphasizing their social relationships and collaborations, he also brings to life the network of the Royal Society in London.

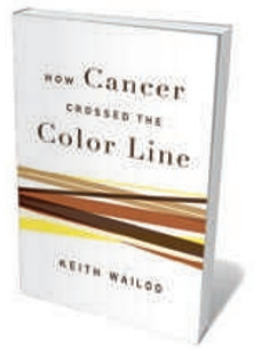

\section{How Cancer Crossed the Color Line}

Keith Wailoo OXFORD UNIVERSITY PRESS 264 pp. \$27.95 (2011)

Cancer awareness and treatment have a strong socio-political element. Attitudes to race have influenced cancer concerns throughout the twentieth century in the United States, finds historian Keith Wailoo in his study of medical, cultural and sociological factors around the illness. From being an affliction that was mainly associated with white women, cancer has crossed cultural boundaries. But race, class and gender issues linger, for example in reports of high rates of breast cancer in affluent parts of California and in the poor health outcomes for black men with prostate cancer.

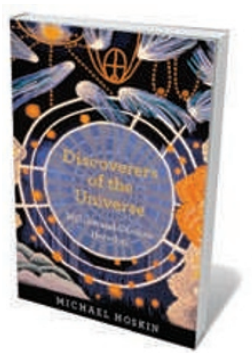

Discoverers of the Universe: William and Caroline Herschel Michael Hoskin PRINCETON UNIVERSITY PRESS 272 pp. \$29.95 (2011) With the help of his sister Caroline, the eighteenth-century GermanBritish astronomer William Herschel discovered the planet Uranus, revealed infrared radiation and coined the term asteroid. In this joint biography, written with the cooperation of the Herschel family, historian of astronomy Michael Hoskin portrays the siblings' shared passion for the night sky, and the triumphs and pitfalls of their work. Using an amateur telescope, the pair charted thousands of stars and nebulae in catalogues that are still used today. Caroline's role as one of the first professional women astronomers is also recognized.

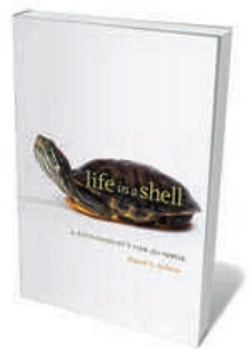

Life in a Shell: A Physiologist's View of a Turtle

Donald C. Jackson HARVARD UNIVERSITY PRESS 192 pp. \$29.95 (2011) Over 200 million years of existence, turtles have shared the planet with dinosaurs, witnessed the diversification of mammals and seen the spread of humans. Physiologist Donald Jackson conveys his love of the reptile in his book. He explains how its slow movements help it to survive winters under ice and describes how its shell functions as a home, armour and a buoyancy aid. By focusing on the physiology of this one familiar beast, he also reveals how scientific understanding evolves by building on the work of others. 